\title{
RESULTS OF RIBES BREEDING AT THE NATIONAL UNIVERSITY OF LIFE AND ENVIRONMENTAL SCIENCES OF UKRAINE
}

\author{
*Volodymyr Mezhenskyj, Tetiana Kondratenko, Borys Mazur, Nataliia Shevchuk, Yurii Andrusyk, \\ Oksana Kuzminets \\ National University of Life and Environmental Sciences of Ukraine, Ukraine \\ *Corresponding author's email: mezh1956@ukr.net
}

\begin{abstract}
Breeding work on Ribes species has been started at the National University of Life and Environmental Sciences of Ukraine in Kyiv since 1984 by Petro Sherenhovyj. The breeding programme has been focused on fruit quality, yield, resistance to diseases and pests, as well as on adaptive responses to environmental conditions. As a result of the long-term work, 18 new cultivars were included in the State Register of Plant Varieties of Ukraine in 19992016. The aim of this paper is to describe these varieties: 10 blackcurrant ('Dochka Vorskly', 'Hovtva', 'Pam 'yati Leonida Mykhalevskoho', 'Universytetska', 'Aspirantska', 'Didorivska', 'Poltava 584', 'Petrivska', 'Yuvileina Sherenhovoho', and 'Leleka'), 5 redcurrant ('Kyianochka', 'Poliana Holosiivska', 'Buzhanska', 'Malva', and 'Olha'), 1 whitecurrant ('Lebidka'), and 2 gooseberry ('Vasylko', and 'Tikych'). The varieties described give farmers and scientists the best knowledge about these cultivars with good level of commercial traits, suitable for dissemination in Ukraine.
\end{abstract}

Key words: blackcurrant, whitecurrant, redcurrant, goldencurrant, gooseberry, cultivars.

\section{Introduction}

The genus Ribes L. (Grossulariaceae) includes some edible gooseberries and currants which are among popular small fruit crops in Ukraine. Fruit currants are divided into blackcurrant (R. nigrum L.), red and whitecurrant (Ribes petreum Wulfen, R. rubrum L., $R$. spicatum E. Robson and their interspecies hybrids) and goldencurrant ( $R$. aureum Pursh.). Most gooseberry cultivars belong to hybrids between European R. uva-crispa L. and some American species. Both gooseberry and currant cultivars are widely grown in commercial and amateur orchards in Ukraine. Ribi occupy quite significant areas of small fruit crops in Ukraine. The area of currant plantations at bearing age makes 4.8 thousand ha and the area of the gooseberry plantations makes 0.5 thousand ha, which are $24.1 \%$ and $2.5 \%$ of total berries area, respectively. Ukrainian currant production estimated annually is estimated roughly at 27.1 thousand t, and gooseberry production is estimated at 7.8 thousand $t$ (State..., 2018). The State Register of Plant Varieties Suitable for Dissemination in Ukraine in 2020 (Ministry..., 2020) includes 26 blackcurrant cultivars, 11 red and white currant cultivars, and 21 gooseberry cultivars. The main breeding institutions in this field in Ukraine are Institute of Horticulture, including Lviv Experimental Station and Mliiv Experimental Station of Pomology, and National University of Life and Environmental Sciences of Ukraine (bellow written as NULESU) (Bronovytska, 2013).

The breeding work on Ribes was started at the NULESU (former Ukrainian Agricultural Academy) in 1984 (Sherenhovyi, 2011). Petro Sherengovyi, as the founder of the breeding program, used methods of cross breeding, either via controlled crosses or via open pollination as well as bud sports. Initial material was the varieties of small fruit crop early collected by Sherenhovyi which included a lot of berries, including 98 blackcurrant cultivars. Selections were made in large number of seedlings based initially on subjective evaluation of fruit quality, yield, and plant health. The breeding tasks in blackcurrant breeding are stable high yield (10-15 $\left.\mathrm{t} \mathrm{ha}^{-1}\right)$, large fruit (1.5-2.5 g), high vitamin C content (150-200 mg $\left.100 \mathrm{~g}^{-1}\right)$, adaptability to mechanized harvesting, and resistance to pests and diseases (Sedov, 1995). The yield size and fruit quality strongly dependended on the environment (Zhuchenko, 1988). The final selections were used for the observation and replicated plots, and other studying (Sherenhovyj, 1999; Kondratenko \& Sherenhovyi, 2007; Havuk, 2008; Silenko \& Havuk, 2013). Most promising selections were tested according to guidelines for distinctness, uniformity, and stability tests and registered in Ukraine as new cultivars. The employees of the Department of Horticulture participated in the development of a number of Sherenhovyi's breeding varieties. Brief information about some varieties given by the principal breeder (Sherenhovyj, 1999, 2011) needs to be supplemented. The aim of this paper is to review all cultivars of Ribes species developed at the NULESU.

\section{Materials and Methods}

The blackcurrant, white currant, redcurrant, and gooseberry cultivars developed at the NULESU were recollected in the new collection. The collection site was established in the training laboratory 'Fruit and Vegetable Garden' of the NULESU in 2015-2016. The studies were carried out according to generally accepted methods (Sedov, 1995; Sedov \& Ogoltsova, 1999). A monograph method was used during studying process for describing. The description of 
18 registered varieties is reported below, including 10 blackcurrant, 5 redcurrant, 1 whitecurrant, and 2 gooseberry cultivars.

\section{Results and Discussion}

\section{Registered blackcurrant cultivars}

'Dochka Vorskly' was obtained from open pollination of 'Vorskla' in 1978. The plants are resistant to powdery mildew (causal agent Podosphaera morsuvae (Schwein.) U. Braun \& S. Takam.) and white pine blister rust (causal agent Cronartium ribicola J. C. Fisch.), and medium resistant to septoriosis (causal agent Mycosphaerella ribis (Fuckel) Lindau). Cultivar is suitable for a combine harvester. Cropping is stable and abundant $\left(16 \mathrm{t} \mathrm{ha}^{-1}\right)$. The plants are medium-sized with thick first grow shoots. The strigs are medium, medium-dense. The berries are wideoval, black, shiny, attractive. The average fruit weight is $1.5 \mathrm{~g}$, the largest fruit is up to $3.5 \mathrm{~g}$. The skin is thick, but not rough, dense. The flesh is greenishbraun, a pleasant sour-sweet, slightly currant aroma. The berries have soluble solids (18.5-20.8\%), sugars $(8.6 \%)$, organic acids (1.8\%), vitamin C (up to $200 \mathrm{mg} 100 \mathrm{~g}^{-1}$ ). Ripening season is medium-early. Fruit is used for fresh consumption and freezing as well as for various types of technical processing. The variety was included to the State Register of Plant Varieties of Ukraine in 1999.

'Hovtva' was obtained from open pollination of 'Poltava 800'× 'Belorusskaya Sladkaya' in 1978. The plants are resistant to powdery mildew and white pine blister rust. Cropping is stable and abundant (15 tha $\left.{ }^{1}\right)$. The plants are medium-sized, semi-spreading. The first grow branches are thick, upright. The strigs are middle to long. The average fruit weight is $1.3 \mathrm{~g}$, the largest fruit is up to $2.6 \mathrm{~g}$. The skin is not thick, tight. The flesh is greenish-brown, pleasantly sour-sweet in taste. The berries have soluble solids (13.1\%), sugars (7.6\%), organic acids (3.2\%), vitamin C (190 mg 100 $\left.\mathrm{g}^{-1}\right)$. Ripening season is medium. Fruit is used for processing. The variety has been included in the State Register of Plant Varieties of Ukraine since 1999.

'Pam 'yati Leonida Mykhalevskoho' is a sport of 'Mriia Kyivska' (= 'Nestor Kozin' $\times$ 'Seenets Golubki'). The plants are resistant to powdery mildew and septoriosis, only in some years affected by white pine blister rust. Cropping is stable and abundant $\left(18-20 \mathrm{t} \mathrm{ha}^{-1}\right)$. The plants are medium-sized, semispreading, with dark green leaves. The strigs are medium, dense, at 2-3 in node. The berries are roundoval, black, shiny. The average fruit weight is $1.2 \mathrm{~g}$, the largest fruit is up to $3.0 \mathrm{~g}$. The skin is tight, elastic. The flesh is greenish-yellow, sour-sweet, slightly of currant aroma. The berries have soluble solids (13.2$14.7 \%)$, sugars (7.9-8.2\%), organic acids (2.0-2.4\%), vitamin C (195-220 mg $\left.100 \mathrm{~g}^{-1}\right)$. Ripening season is mid-late. Fruit is used for fresh consumption, freezing, and processing. The variety was included in the State Register of Plant Varieties of Ukraine in 2007.

'Universytetska' was obtained from open pollination of 'Holosiivska' (= 'Poltava 800 '× 'Zelena Dymka') in 1992. The plants are resistant to powdery mildew and white pine blister rust. Cultivar is suitable for a combine harvester. Cropping is stable and abundant $\left(19 \mathrm{t} \mathrm{ha}^{-1}\right)$. The plants are medium-sized, compact. The first grow branches are thick, yellowbrown, with pink-purple densely arranged buds. The strigs are long, medium-dense, abundant, up to 12 berries. The berries are round-oval, black, shiny. The average fruit weight is $1.2 \mathrm{~g}$, the largest fruit up to $3.0 \mathrm{~g}$. The skin is thin, but tight. The flesh is yellowish-greenish, pleasantly sour-sweet in taste, with a slight currant aroma. The berries have soluble solids $(16.1 \%)$, sugars $(8.4 \%)$, organic acids $(3.5 \%)$, vitamin C (215-230 mg $\left.100 \mathrm{~g}^{-1}\right)$. Ripening season is mid-late. Fruit is used for fresh consumption as well as for various types of technical processing. The variety has been included in the State Register of Plant Varieties of Ukraine since 2007.

'Aspirantska' was obtained by crossing 'Mriia Kyivska' (= 'Nestor Kozin' $\times$ 'Seenets Golubki') $\times$ 'Narodna' ( $=\mathrm{F}_{1}$ 'Lentyaj') in 1995. The plants are self-fertile, resistant to fungal diseases, only in some years they were affected by powdery mildew. Drought resistance is high. Cropping is abundant $\left(15 \mathrm{t} \mathrm{ha}^{-1}\right)$. The plants are medium-sized, compact; branches are thick. The leaves are small, light green. The strigs are medium to long averaging 6-8 large berries. The berries are round, black, shiny. The average fruit weight is $1.8 \mathrm{~g}$, the largest fruit - up to $3.8 \mathrm{~g}$. The skin is of medium density, elastic. Flesh is greenish-yellow, with a very pleasant sour-sweet taste. The berries have soluble solids (13.7-14.2\%), sugars (9.2-10.3\%), organic acids (2.4-2.5\%), vitamin C (241-263 mg $100 \mathrm{~g}^{-1}$ ). Ripening season is medium. The fruit does not fall off for a long time. They are suitable for fresh consumption as well as for freezing and processing. The variety has been included in the State Register of Plant Varieties of Ukraine since 2008.

'Didorivska' was obtained by crossing 'Dochka Vorskly' (= $\mathrm{F}_{1}$ 'Vorskla') × 'Mriia Kyiva' (= 'Nestor Kozin' $\times$ 'Seenets Golubki') in 1995. The plants are self-fertile, resistant to powdery mildew, only in some years they were affected by white pine blister rust. Drought resistance is high. Cropping is abundant $(17 \mathrm{t}$ $\left.\mathrm{ha}^{-1}\right)$. The plants are medium-sized to large, compact; branches are thick, elastic. The leaves are five-lobed, dark salad coloration, lighter on the tips of shoots; lower lobe is slightly expressed; margin is sharply toothed; petioles are long. The strigs are medium to long averaging 6-8 large berries. The berries are round-oval, black, shiny, attractive. The average 
fruit weight is $1.9 \mathrm{~g}$, the largest fruit is up to $4.3 \mathrm{~g}$. The skin is dense, elastic. Flesh is greenish-yellow, pleasantly sour-sweet in taste. The berries have soluble solids (13.7-14.2\%), sugars (9.2-10.2\%), organic acids (2.4-2.6\%), vitamin C (238-251 mg $\left.100 \mathrm{~g}^{-1}\right)$. Ripening season is middle. The fruit does not fall off for a long time. They are suitable for fresh consumption, freezing, and processing. The variety has been included in the State Register of Plant Varieties of Ukraine in 2009.

'Poltava 584' ('Poltava Pokrashchena') was obtained by crossing 'Poltava 800' (= 'Zoya' $\times$ (Prymorskij Chempion') $\times$ 'Titania' in 1995. The plants are field resistant to powdery mildew. Cropping is abundant, up to $6 \mathrm{~kg}$ per bush. The plants are vigorous, compact, with many shoots. The strigs are medium. The berries are round, black, shiny. The average fruit weight is $1.8 \mathrm{~g}$, the largest fruit - up to $4.5 \mathrm{~g}$. The skin is dense, elastic. The flesh is yellowish and light greenish, sweet and sour in taste. The berries have soluble solids $(13.9 \%)$, sugars $(10.8 \%)$, pectins (1.9\%), organic acids (3.1-3.2\%), vitamin C (215$\left.320 \mathrm{mg} 100 \mathrm{~g}^{-1}\right)$. They are used for fresh consumption, as well as for jam, juices, jellies, wine, and freezing. The variety has been included in the State Register of Plant Varieties of Ukraine since 2014.

'Petrivska' was obtained by crossing 'Mriia Kyivska' (= 'Nestor Kozin' $\times$ 'Seenets Golubki') $\times$ 'Holosiivskyi Veleten' [= 'Pam 'yatna' $\times$ ('Perun' $\times$ 'Titania')] in 1990. The plants are resistant to powdery mildew and anthracnose (causal agent Drepanopeziza ribis (Klebahn) von Höhnel), medium resistant to white pine blister rust and blackcurrant gall mite (Cecidophyopsis ribis (Westwood 1869)). Cropping is abundant $-3.9 \mathrm{~kg}$ per bush $\left(18.6 \mathrm{t} \mathrm{ha}^{-1}\right)$. The plants are medium-sized, often large, spreading. The shoots are thick, gray. The strigs are medium. The berries are black, relatively transportable. The average fruit weight is $1.6 \mathrm{~g}$, the largest fruit is up to $4.5 \mathrm{~g}$. The flesh is greenish, sour-sweet. The berries have soluble solids $(14.5 \%)$, sugars $(8.1-8.3 \%)$, organic acids (3.3$3.5 \%)$, vitamin C (190-250 mg 100 g $\left.\mathrm{g}^{-1}\right)$. The harvest is mid-season. The variety has been included in the State Register of Plant Varieties of Ukraine since 2015.

'Yuvileina Sherenhovoho' is a sport of 'Holosiivskyi Veleten' [= 'Pam 'yatna' $\times$ ('Perun' $\times$ 'Titania')]. The plants are resistant to fungal diseases. Cropping is abundant - 4-7 kg per bush (18-24 tha-1). The plants are medium-sized, often large, spreading. The shoots are thick, gray. The strigs are short. The berries are black, early ripening. The average fruit weight is $1.8 \mathrm{~g}$, the largest fruit is up to $2.4 \mathrm{~g}$. The flesh is greenish-yellow, sour-sweet in taste. The berries have soluble solids $(14.5 \%)$, sugars $(8.2 \%)$, pectins $(1.7 \%)$, organic acids $(3.4 \%)$, vitamin $\mathrm{C}$ (220 mg $\left.100 \mathrm{~g}^{-1}\right)$. The variety has been included in the State Register of Plant Varieties of Ukraine since 2016.

'Leleka' was obtained by crossing 'Mriia Kyiva' $(=$ 'Nestor Kozin' $\times$ 'Seenets Golubki') $\times$ 'Narodna' ( $=\mathrm{F}_{1}$ 'Lentyaj') in 1995 . The plants are self-fertile, resistant to powdery mildew, anthracnose, and white pine blister rust. Cultivar is suitable for a combine harvester. The plants are vigorous, compact. The shoots are elastic, thick. The strigs are long averaging 8-12 large berries. The berries are round-oval, black, shiny. The average fruit weight is $1.7 \mathrm{~g}$, the largest fruit is up to $3.5 \mathrm{~g}$. The skin is thin, but tight. The flesh is tight, elastic. The flesh is greenish-yellow, sweet and sour, aromatic. The berries have soluble solids (14.2$14.6 \%)$, sugars (8.4-9.2\%), organic acids (2.2-3.0\%), vitamin C (225-236 mg $\left.100 \mathrm{~g}^{-1}\right)$. Ripening season is medium. Fruit is used for fresh consumption, freezing, and various types of technical processing (juices, jellies, compotes, and wine materials). The variety has been included in the State Register of Plant Varieties of Ukraine since 2017.

\section{Registered redcurrant cultivars}

'Kyianochka' was obtained by crossing 'Jonkheer van Tets' $\times$ 'Fay's Prolific' in 1986. The plants are resistant to most fungal diseases, but they are susceptible to septoriosis. Cropping is stable and abundant $\left(21 \mathrm{tha}^{-1}\right)$. The plants are vigorous in youth, and medium-sized with age, slightly spreading. The shoots are thick. The leaves are medium-sized, dark green, slightly curved inside. The strigs are medium to long, having up to 17 berries. The berries are dark red, round, attractive for early season. The average fruit weight is $0.9 \mathrm{~g}$, the largest fruit is up to $1.0 \mathrm{~g}$. The flesh is light pink, sweet and sour, aromatic. The berries have soluble solids $(11.0 \%)$, sugars $(6.9 \%)$, pectins $(0.4 \%)$, organic acids $(2.7 \%)$, vitamin C $(47.0 \mathrm{mg}$ $\left.100 \mathrm{~g}^{-1}\right)$. They are used for processing, especially for jelly and juice. The variety has been included in the State Register of Plant Varieties of Ukraine since 2012.

'Poliana Holosiivska' was obtained by crossing 'Buzhanska' × ('Jonkheer van Tets' + 'Kyianochka') in 1999. The plants are resistant to powdery mildew and anthracnose, and semi-resistant to septoriosis. Cropping is very abundant (up to $24 \mathrm{t} \mathrm{ha}^{-1}$ ). The plants are medium-sized with age, slightly spreading. The strigs are very long. The berries are bright red, shiny. Average fruit weight is $0.8 \mathrm{~g}$. The berries have soluble solids $(11.1 \%)$, sugars $(7.0 \%)$, pectins $(0.4 \%)$, organic acids $(2.6 \%)$, vitamin $\mathrm{C}\left(46.0 \mathrm{mg} 100 \mathrm{~g}^{-1}\right)$. Ripening season is medium. The fruit is used for processing. The variety has been included in the State Register of Plant Varieties of Ukraine since 2012.

'Buzhanska' was obtained by crossing 'Fay's Prolific' $\times$ 'Red Cross' in 1994. The plants are tolerant to powdery mildew, anthracnose, and septoriosis. Cropping is abundant $\left(22 \mathrm{t} \mathrm{ha}^{-1}\right)$. The plants are 
medium-sized, slightly spreading. The shoots are thick, strong, and elastic. The strigs are medium to long, averaging 10-14 berries. The berries are bright red, attractive. The average fruit weight is $0.9 \mathrm{~g}$, the largest fruit up to $1.5 \mathrm{~g}$. The skin is thin but tight. The flesh is light red, with sweet and sour taste. The berries have soluble solids $(11.9 \%)$, sugars $(8.9 \%)$, organic acids (2.4\%), vitamin C (58.4 mg $\left.100 \mathrm{~g}^{-1}\right)$. Ripening season is early-middle/ mid-early?. Fruit is used for fresh consumption as well as for processing, including wine, juice, jelly, and freezing. The variety has been included in the State Register of Plant Varieties of Ukraine since 2014.

'Malva' was obtained by crossing 'Poliana Holosiivska' × ('Buzhanka' + 'Kyianochka') in 1999. The plants are resistant to anthracnose and septoriosis. Cropping is abundant $\left(22 \mathrm{t} \mathrm{ha}^{-1}\right)$. The plants are compact. The shoots are thick, strong, and elastic. The strigs are long, up to 22 berries. The berries are slightly oval, dark red, shiny. The average fruit weight is $0.8 \mathrm{~g}$, the largest fruit - up to $1.2 \mathrm{~g}$. The skin is thin, but tight. The flesh is light red, with sweet and sour taste. The berries have soluble solids $(11.2 \%)$, sugars $(8.0 \%)$, pectins $(0.4 \%)$, organic acids $(2.5 \%)$, vitamin C (49.5 mg $\left.100 \mathrm{~g}^{-1}\right)$. Fruit is used for fresh consumption, freezing, and processing. The variety has been included in the State Register of Plant Varieties of Ukraine since 2014.

'Olha' was obtained by crossing 'Buzhanka' $\times$ 'Kyianochka' in 2003. The plants are resistant to powdery mildew, anthracnose, and septoriosis. Cropping is abundant (4.5 kg per bush or $21.4 \mathrm{t} \mathrm{ha}^{-1}$ ). The plants are robust, a little spreading, with thick shoots. The strigs are middle-sized averaging 10 12 large berries. The berries are dark red. The average fruit weight is $1.2 \mathrm{~g}$, the largest fruit is up to $1.8 \mathrm{~g}$. The skin is thin, but tight. The flesh is light pink, sweet and sour in taste. The berries have soluble solids (12.5\%), sugars $(8.0 \%)$, organic acids $(2.9 \%)$, vitamin C $\left(62.5 \mathrm{mg} 100 \mathrm{~g}^{-1}\right)$. Fruit is used for fresh consumption and processing. The variety has been included in the State Register of Plant Varieties of Ukraine since 2016. Registered whitecurrant cultivar

'Lebidka' obtained from open pollination seed of unknown variety. The plants are tolerant to fungal diseases. Cropping is abundant (up to $23 \mathrm{t} \mathrm{ha}^{-1}$ ). The plants are medium-sized, slightly spreading. The shoots are thick, strong, and elastic, required pinching or trimming for branching. The leaves are trilobate, original shape, with lateral lobes, elongated parallel to the central vein. The strigs are medium-size. The berries are round, white, transparent, sour-sweet, richtasting. The average fruit weight is $0.9 \mathrm{~g}$, the largest fruit - up to $1.3 \mathrm{~g}$. The skin is thin. The berries have soluble solids $(13.2 \%)$, sugars $(6.6-8.0 \%)$, pectins (0.4\%), organic acids (1.1-1.2\%), vitamin C (65.0 mg $\left.100 \mathrm{~g}^{-1}\right)$. Ripening season is early. Fruit is used for fresh consumption and all kind of processing, especially for wine making. The variety has been included in the State Register of Plant Varieties of Ukraine since 2014.

\section{Registered gooseberry cultivars}

'Vasylko' was obtained by crossing 'Finik' $\times$ 'NAU 1' (= $F_{1}$ 'Afrykanets'). The plants are very productive, spineless, resistant to powdery mildew. They are medium-sized with inclined shoots. Young leaves are dark green, acute at the base. The flowers have moderate anthocyanin coloration. The berries are round-oval, light green, without pubescence. The average fruit weight is $2.9-3.3 \mathrm{~g}$, the largest fruit is above $5.0 \mathrm{~g}$. The skin is semi-thick, dense, elastic, with clearly visible subcutaneous veins. The flesh is greenish, sour-sweet. The berries have soluble solids $(12.0 \%)$, sugars $(5.3 \%)$, organic acids $(2.4 \%)$, vitamin C (36.0-40.3 mg $\left.100 \mathrm{~g}^{-1}\right)$. Fruit is used for fresh consumption, freezing, and processing. The variety has been included in the State Register of Plant Varieties of Ukraine since 2013.

'Tikych'was obtained by crossing 'Neslukhovskyi' $\times$ 'Afrykanets' in 1995. The plants are very productive, spineless, resistant to powdery mildew and septoriosis. Cropping is very abundant $(10 \mathrm{~kg}$ her bush or $\left.30 \mathrm{tha}^{-1}\right)$. The plants are medium-sized; the thick shoots are moderately covered with single and double spines. Flowering usually begins around April 20 and ends around May 1. The first harvest comes in late June. The berries are oval, violet-red. The average fruit weight is $3.8 \mathrm{~g}$, the largest fruit - up to $7.0 \mathrm{~g}$. The berries have soluble solids $(14.1 \%)$, sugars $(8.2 \%)$, organic acids $(2.5 \%)$, vitamin C (55.5 mg $\left.100 \mathrm{~g}^{-1}\right)$. Fruit is used for fresh consumption, freezing, as well as for various types of processing. The variety has been included in the State Register of Plant Varieties of Ukraine since 2013.

\section{Goldencarrant cultivars}

In the NULESU, while carrying out the breeding programme on Ribes species, some goldencurrant cultivars, such as 'Monastyrska', 'Perlyna Didorivky', 'Pyriatynska', 'Vyshneva', 'Yantarna' and others were also developed. Goldencurrant is popular in amateur gardening, but there are not registered cultivars yet.

The new varieties developed at NULESU correspond to breeding tasks. They are resistant to main diseases, have high fruit quality, suitability for fresh market and processing, and good adaptability to condition of the northern part of Ukraine. Their drought tolerance may allow them to occupy a wider cultural range in a changing climate. Similarly, successful results in both red and white currants breeding as well as gooseberry breeding in terms of productivity and fruits quality in order to meet the set breeding tasks were obtained. Due to this, new 
varieties are in demand by farmers. There is a great potential for further improvement of these small fruit crops. The cultivars developed at the NULESU and involved in breeding is good basis for new better varieties with high level of commercial traits.

\section{Conclusions}

The total number of Ribes cultivars developed in the NULESU and included in the State Register of Plant Varieties of Ukraine in 1999-2016 was 18. These consisted of 10 blackcurrant, 5 redcurrant, 1 whitecurrant, and 2 gooseberry cultivars. They are resistant to main diseases, have high fruit quality, suitability for fresh market and processing, and good adaptability to local condition. The descriptions allow both farmers and scientists to know better the varieties suitable for dissemination in Ukraine.

\section{References}

Bronovytska, M.А. (2013). Особливості формування сортових ресурсів смородини чорної (Ribes nigrum L.) в Україні (Peculiarities of blackcurrant (Ribes nigrum L.) varietal resources development in Ukraine). Plant Varieties Studying and Protection. 9(2), 15-19. (in Ukrainian).

Havyuk, P.M. (2008). Urazhennia khvorobamy sortiv smorodyny chornoi (Ribes nigrum L.) selektsii NAU (Affection of blackcurrant (Ribes nigrum L.) varieties of National Agrarian University by diseases). Plant Varieties Studying and Protection. 4(1), 114-119. (in Ukrainian).

Kondratenko, T.Ye., \& Sherenhovyi, P.Z. (2007). Selektsiia ta vyrobnytstvo plodiv smorodyny chornoi (Breeding and cultivation of black currant). Sadivnytsvo. 60, 159-168. (in Ukrainian).

Ministry of Agricultural Policy and Food of Ukraine. Derzhanvyi reiestr sortiv roslyn Ukrainy prydatnykh dlia poshyrennia v Ukraini v 2020 (State Register of Plant Varieties Suitable for Dissemination in Ukraine in 2020). (2020). Retrieved March 26, 2020, from https://sops.gov.ua/reestr-sortiv-roslin. (in Ukrainian).

Sedov, E.N. (Ed.). (1995). Programma i metodika selektsii plodovykh, yagodnykh i orekhoplodnykh kultur (Programme and methods of breeding of fruit, small fruit, and nut crops). Orel: All-Russian Res. Inst. Breeding Fruit Crops. (in Russian).

Sedov, E.N., \& Ogoltsova, T.P. (Eds.). (1999). Programma i metodika sortoizucheniya plodovykh, yagodnykh i orekhoplodnykh kultur (Programme and methods of varietal study of fruit, small fruit, and nut crops). Orel: All-Russian Res. Inst. Breeding Fruit Crops. (in Russian).

Sherenhovyi, P.Z. (1999). Selektsiia yahidnykh kultur (Breeding of small fruit crops). Sadivnytsvo. 48, 58-62. (in Ukrainian).

Sherenhovyi, P.Z. (2011). Moie zhyttia - v moikh sortakh (My life is in my varieties). Vinnytsia: FOP D. Yu. Korzun. (in Ukrainian).

Silenko, V.O., \& Havyuk, P.M. (2013). Придатність сортів смородини (Ribes nigrum L.) селекції НУБіП України до механізованого збирання ягід (Suitability of black currant (Ribes nigrum L.) as bred by NULES of Ukraine to machine harvesting of its berries). Plant Varieties Studying and Protection. 9(3), 13-17. (in Ukrainian).

State Statistics Service of Ukraine. (2018). Silske hospodarsto Ukrainy: Statystychnyi shchorichnyk 2017 (Agriculture of Ukraine: Statistical Yearbook 2017). Retrieved February 20, 2018, from http://www. ukrstat.gov.ua/druk/publicat/kat_u/2018/zb/09/zb_sg2017_pdf.pdf. (in Ukrainian).

Zhuchenko, A.A. (1988). Adaptivnyj potentsial kulturnykh rastenij: ekologo-geneticheskiye ocnovy (Adaptive potential of cultivated plants: ecologo-genetic basics). Kishinev: Shtiintsa (in Russian). 